\title{
Street Cleaning Trucks as Potential Sources of Legionella pneumophila
}

\author{
Natalia Valero, Mercè de Simón, \\ Pau Gallés, Neus Izquierdo, Jaume Arimon, \\ Raquel González, Sandra Manzanares-Laya, \\ Ingrid Avellanes, Anna Gómez
}

In 2015, Legionnaires' disease was diagnosed in a street cleaning worker. We found Legionella pneumophila serogroup 1 in the water and internal foam from the tanks of 2 trucks used by the worker during the incubation period. The internal foam was removed, and a Legionella prevention program was implemented.

$\mathrm{L}$ egionnaires' disease (LD) is an acute pneumonia caused by inhalation or aspiration of aerosols contaminated with Legionella bacteria. Legionella spp. are ubiquitous in freshwater aquatic habitats. Multiplication of Legionella in artificial water systems is facilitated by temperatures around $35^{\circ} \mathrm{C}$ and factors such as lack of disinfection, water stagnation, and poor maintenance (1).

In Spain, 925 cases of LD were reported in 2014, of which $82 \%$ were sporadic cases, not related to outbreaks (2). LD outbreaks have been related to cooling towers, spa pools, and water distribution systems (2-4), which are considered by regulations in Spain to have a high probability of proliferation of Legionella (5).

The identification of exposure in sporadic cases provides a good opportunity to enhance understanding of reservoirs for Legionella in relatively rare sources $(6,7)$. This case report summarizes the environmental study conducted to identify the possible source of exposure of a street cleaning worker who contracted LD.

\section{The Study}

A 58-year-old man in Barcelona who smoked began to show symptoms compatible with legionellosis on July 27, 2015. On August 11, LD was diagnosed in the patient; this diagnosis was confirmed by a urinary antigen test (UAT). On August 14, the case was reported to the Public Health Agency of Barcelona.

Author affiliations: Agència de Salut Pública de Barcelona, Barcelona, Spain (N. Valero, M. de Simón, P. Gallés, N. Izquierdo, J. Arimon,

R. González, S. Manzanares-Laya, I. Avellanes, A. Gómez); Centro de Investigación Biomédica en Red de Epidemiología y Salud Pública (CIBERESP), Barcelona (S. Manzanares-Laya)

DOI: https://doi.org/10.3201/eid2311.161390
A trained public health practitioner interviewed the affected patient by using a standardized questionnaire to obtain information on demographic data, personal risk factors, and activities during the 15 days before the onset of illness. The only exposure to sources of aerosolized water highlighted by the epidemiologic survey was an occupational exposure to high-pressure water hoses from street cleaning trucks during the incubation period. The trucks used had 2- $\mathrm{m}^{3}$ water tanks with an internal foam lining $\approx 15 \mathrm{~cm}$ thick. The purpose of the foam was to help steady the truck when in motion. The truck tanks were filled with groundwater untreated with chlorine or with drinking water from the town's water supply network, depending on their availability during the journey. At the end of the day, the tanks were emptied but the internal foam remained impregnated with water. Once a year, the tanks were disinfected with a 20-ppm chlorine solution for 2 hours; hoses were replaced relatively often because of deterioration. However, the interior walls of the tanks were never cleaned, and the foam lining was never replaced.

Three days after the interview, we took samples from the 4 trucks that the worker used in the 15 days before symptom onset. We took water samples and smears from the hoses and water tanks to test them for Legionella. We also took a water sample from the groundwater tank where the trucks were usually filled.

We analyzed the samples in accordance with the ISO 11731 method for counting Legionella spp. (8). In addition, we obtained counts of $L$. pneumophila serogroup 1 and of serogroups 2-15. We performed molecular typing of the strains of L. pneumophila serogroup 1 isolated in the different samples via DNA macrorestriction and subsequent pulsed field electrophoresis. We calculated the similarity coefficient and displayed the results of molecular typing as a dendrogram generated by the FPQuest software package (Bio-Rad Laboratories, Hercules, CA, USA).

Water sample temperatures ranged from $26^{\circ} \mathrm{C}$ to $28^{\circ} \mathrm{C}$. We detected L. pneumophila serogroup 1 in the water from 2 of the 4 trucks sampled. L. pneumophila serogroup 1 counts were $150 \mathrm{CFU} / \mathrm{L}$ for truck 1 and 1,000 CFU/L for truck 2 (Table). We did not detect Legionella in the sample of the groundwater tank or in the hose smears of either truck.

After Legionella detection, the tanks were disinfected and cleaned following the cleaning procedure described by law for hot water systems (5). After 15 days, we drew new 
Table. Counts of Legionella pneumophila serogroups 1 and 2-15 in the samples of water, foam, and smears analyzed before and after cleaning and disinfection of 2 street cleaning trucks, Barcelona, Spain, 2015*

\begin{tabular}{|c|c|c|c|c|}
\hline \multirow[b]{2}{*}{ Location and sample type } & \multicolumn{2}{|c|}{ Before cleaning and disinfection, CFU/L } & \multicolumn{2}{|c|}{ After cleaning and disinfection, CFU/L } \\
\hline & $\begin{array}{l}\text { L. pneumophila } \\
\text { serogroup } 1\end{array}$ & $\begin{array}{l}\text { L. pneumophila } \\
\text { serogroups } 2-15\end{array}$ & $\begin{array}{l}\text { L. pneumophila } \\
\text { serogroup } 1\end{array}$ & $\begin{array}{c}\text { L. pneumophila } \\
\text { serogroups } 2-15\end{array}$ \\
\hline \multicolumn{5}{|l|}{ Truck 1} \\
\hline Water tank & 150 & $<1 \dagger$ & 400 & $<1$ \\
\hline Hose water & 150 & $<1$ & 5,700 & $<1$ \\
\hline Foam sample 1 & NA & NA & $250 \ddagger$ & Not detected \\
\hline Foam sample 2 & NA & NA & $5,500 \ddagger$ & Not detected \\
\hline Tank surface smear & NA & NA & Detected & Not detected \\
\hline \multicolumn{5}{|l|}{ Truck 2} \\
\hline Water tank & 1,000 & 1,000 & 125 & 125 \\
\hline Hose water & $<1$ & 50 & $<1$ & 50 \\
\hline Foam sample 1 & NA & NA & $275 \ddagger$ & $125 \ddagger$ \\
\hline Foam sample 2 & NA & NA & $10 \ddagger$ & $10 \ddagger$ \\
\hline Foam sample 3 & NA & NA & Not detected & $10 \ddagger$ \\
\hline Foam sample 4 & NA & NA & $10 \ddagger$ & Not detected \\
\hline Tank surface smear & NA & NA & Not detected & Not detected \\
\hline $\begin{array}{l}{ }^{*} \mathrm{NA}, \text { not analyzed. } \\
\text { †Limit of detection in water } \\
\text { †Counts for } 250 \mathrm{~cm}^{3} \text { of foam }\end{array}$ & & & & \\
\hline
\end{tabular}

water samples to assess the effectiveness of the disinfection, and after 23 days, we took samples of the foam and from the internal surfaces of the tanks of both trucks. We obtained samples of foam by cutting out pieces $(4 \times 4 \times$ $15 \mathrm{~mm}$ ) with a sterile scalpel and placed them in sterile containers with Ringer's solution for subsequent Legionel$l a$ analysis. The results indicated the presence of $L$. pneumophila serogroup 1 in the foam and water tanks of both trucks and in the hose water sample and the smear from the tank of truck 1 (Table).

The results of molecular typing indicated that clones were detected in truck 1 (Dice similarity coefficient 100\%) belonging to the same strain found in the hose water, in the tank water, and in the foam. We also detected another clone, genetically related to the first (Dice similarity coefficient $89 \%$ ), in the tank water, in the smears of the surface of the tank, and in the foam. We identified 2 different molecular patterns in the strains isolated in the tank water and in the foam in truck 2; both patterns appeared in both tank water and foam (Figure). Regarding the foam, we obtained similar results in the foam underneath decorative stones in an ornamental fountain that caused an LD outbreak in a hospital (9).

Weather conditions were warm in July 2015, with an average temperature $>25^{\circ} \mathrm{C}$ even at night (10). These temperatures, along with water stagnation, would have favored proliferation of the bacteria in the water tanks.

Although the mode of transmission is not clear, the high-pressure hose used by the worker probably discharged aerosols containing bacteria that could be inhaled (7). The worker did not use a protective facemask and was the second employee in the same company who was working with cleaning trucks to contract LD. Four years earlier, another case of LD had occurred in similar conditions (J. Cayla,

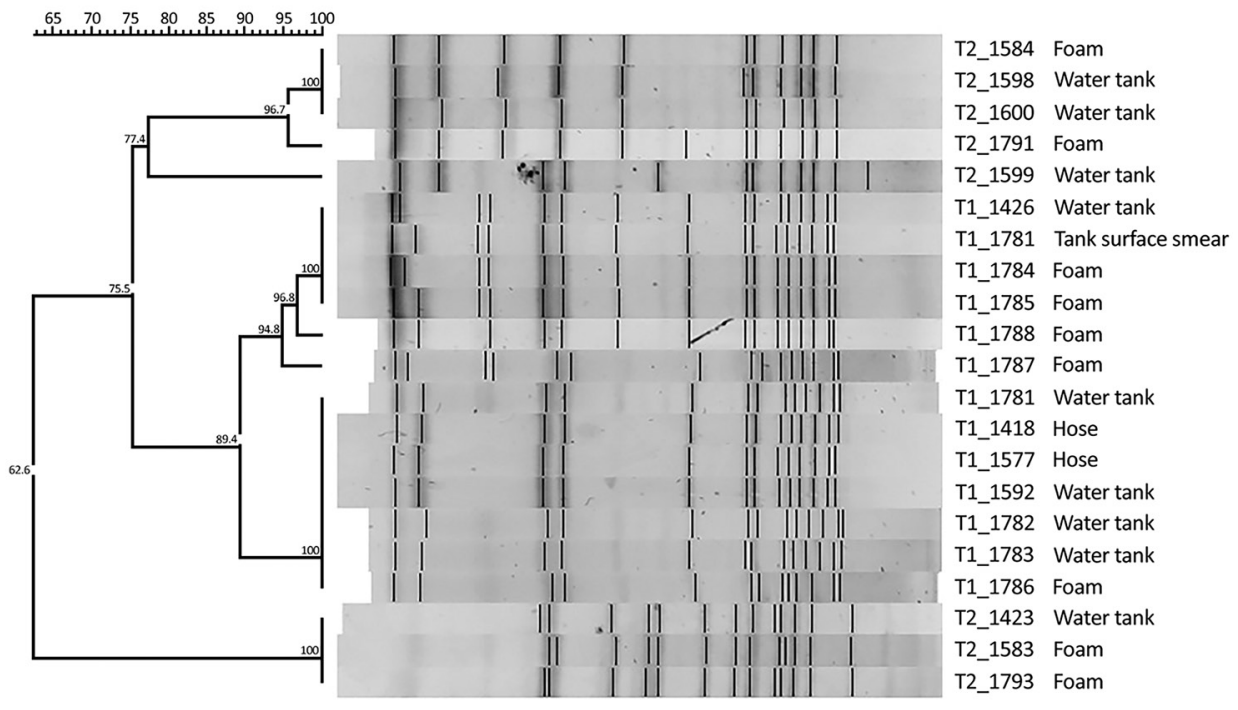

Figure. Dendrogram generated by FPQuest software showing the pattern of Sfil bands for isolates of Legionella pneumophila from 2 street cleaning trucks, Barcelona, Spain, 2015. Strains are identified with code of truck of origin (T1, T2) and an internal number. Scale bar represents Dice similarity coefficient percentage. 
Public Health Agency of Barcelona, pers. comm., 2011 July 22).

Published criteria (11) indicate that cleaning trucks are a potential source of Legionella. The level of evidence of this study corresponds to level III, because L. pneumophila subgroup 1 was isolated in the trucks used by the worker but clinical and environmental strains could not be compared because he was diagnosed by a UAT. Furthermore, because UAT detects only L. pneumophila serogroup 1, lack of respiratory culture can lead to missed diagnoses of other species and serogroups; fortunately, this limitation does not apply here.

A report describing similar exposure concerned an asphalt paving machine causing an outbreak of Legionella in 2009 (6). Like the trucks in this study, this was a mobile source, and the use of untreated water had also contributed to tank pollution. Although some studies have associated LD with occupations such as gardening $(12,13)$ and professional driving (14), no studies have related LD to street cleaning.

\section{Conclusions}

We detected L. pneumophila serogroup 1 in 2 of the 4 trucks used by the affected worker during the incubation period; either truck could have been the source of exposure. The results of this study show that the internal foam of the tanks could act as a reservoir for L. pneumophila and that maintenance and routine cleaning (without removing the foam) did not prevent Legionella proliferation.

After the occurrence of this case, the internal foam in the truck tanks was removed, and the water tanks were cleaned again. The company responsible for the street cleaning trucks adopted a water management plan, with the agreement of the Public Health Agency of Barcelona, based on Hazard Analysis and Critical Control Points methodology (15) and stricter control measures. Workers are now required to wear personal protective equipment during work-related exposure.

Ms. Valero is a public health technician in the Barcelona Public Health Agency in Barcelona, Spain. Her main research interests are environmental health protection research and the study of potential sources of Legionella.

\section{References}

1. Garrison LE, Kunz JM, Cooley LA, Moore MR, Lucas C, Schrag S, et al. Vital signs: deficiencies in environmental control identified in outbreaks of legionnaires' disease-North America, 2000-2014. MMWR Morb Mortal Wkly Rep. 2016;65:576-84. http://dx.doi.org/10.15585/mmwr.mm6522e1

2. European Centre for Disease Prevention and Control. Legionnaires' disease in Europe, 2014. Stockholm: The Centre; 2016 [cited 2016
Jul 23] http://ecdc.europa.eu/en/publications/Publications/ legionnares-disease-europe-2014.pdf

3. García-Fulgueiras A, Navarro C, Fenoll D, García J, González-Diego P, Jiménez-Buñuales T, et al. Legionnaires’ disease outbreak in Murcia, Spain. Emerg Infect Dis. 2003; 9:915-21. http://dx.doi.org/10.3201/eid0908.030337

4. Sánchez-Busó L, Guiral S, Crespi S, Moya V, Camaró ML, Olmos MP, et al. Genomic investigation of a legionellosis outbreak in a persistently colonized hotel. Front Microbiol. 2016;6:1556. http://dx.doi.org/10.3389/fmicb.2015.01556

5. Royal Decree $865 / 2003$, July 4, about sanitary criteria for the prevention and control of legionellosis. BOE núm. 171, 18.07.03 [in Spanish] [cited 2016 Jul 23]. http://www.boe.es/boe/ dias/2003/07/18/pdfs/A28055-28069.pdf

6. Coscollá M, Fenollar J, Escribano I, González-Candelas F. Legionellosis outbreak associated with asphalt paving machine, Spain, 2009. Emerg Infect Dis. 2010;16:1381-7. http://dx.doi.org/10.3201/eid1609.100248

7. Litwin CM, Asebiomo B, Wilson K, Hafez M, Stevens V, Fliermans CB, et al. Recreational vehicle water tanks as a possible source for Legionella infections. Case Rep Infect Dis. 2013;2013:286347. http://dx.doi.org/10.1155/2013/286347

8. Water Quality. Detection and enumeration of Legionella. Part 2: direct membrane filtration method for waters with low bacterial counts (ISO 11731-2:2004) [cited 2017 Aug 17]. https://www.iso.org/standard/32326.html $<$ /eref

9. Haupt TE, Heffernan RT, Kazmierczak JJ, Nehls-Lowe H, Rheineck B, Powell C, et al. An outbreak of Legionnaires' disease associated with a decorative water wall fountain in a hospital. Infect Control Hosp Epidemiol. 2012;33:185-91. http://dx.doi.org/10.1086/663711

10. Spanish Meteorological Agency. Climatological monthly report in July 2015. August 19, 2015 [in Spanish] [cited 2016 Feb 08]. http://www.aemet.es/documentos/es/serviciosclimaticos/ vigilancia_clima/resumenes_climat/mensuales/2015/res_mens clim_2015_07.pdf

11. van Heijnsbergen E, Schalk JAC, Euser SM, Brandsema PS, den Boer JW, de Roda Husman AM. Confirmed and potential sources of legionella reviewed. Environ Sci Technol. 2015;49:4797-815. http://dx.doi.org/10.1021/acs.est.5b00142

12. Piso RJ, Caruso A, Nebiker M. Hose as a source of Legionella pneumonia. A new risk factor for gardeners? J Hosp Infect. 2007;67:396-7. http://dx.doi.org/10.1016/j.jhin.2007.09.008

13. Potts A, Donaghy M, Marley M, Othieno R, Stevenson J, Hyland J, et al. Cluster of Legionnaires' disease cases caused by Legionella longbeachae serogroup 1, Scotland, August to September 2013. Euro Surveill. 2013;18:20656. http://dx.doi.org/10.2807/ 1560-7917.ES2013.18.50.20656

14. Wallensten A, Oliver I, Ricketts K, Kafatos G, Stuart JM, Joseph C. Windscreen wiper fluid without added screenwash in motor vehicles: a newly identified risk factor for Legionnaires' disease. Eur J Epidemiol. 2010;25:661-5. http://dx.doi. org/10.1007/s10654-010-9471-3

15. McCoy WF, Rosenblatt AA. HACCP-based programs for preventing disease and injury from premise plumbing: a building consensus. Pathogens. 2015;4:513-28. http://dx.doi.org/10.3390/ pathogens 4030513

Address for correspondence: Natalia Valero, Agència de Salut Publica de Barcelona, Environmental Quality and Intervention Service, P1 Lesseps 1, Barcelona 08023, Spain; email: nvalero@aspb.cat 